\title{
Properties of conventional and alternative bedding materials for dairy cattle
}

\author{
Patrícia Ferreira Ponciano Ferraz, ${ }^{1 *}$ ๑) Gabriel Araújo e Silva Ferraz, ${ }^{1} \odot$ Lorenzo Leso, ${ }^{2} \odot$ Marija Klopčič, ${ }^{3}$ (]) \\ Matteo Barbari, ${ }^{2}$ (D) and Giuseppe Rossi ${ }^{2}$ (i) \\ ${ }^{1}$ Department of Agricultural Engineering, Federal University of Lavras (UFLA), PO Box 3037, CEP 37200-900 Lavras, Minas Gerais, Brazil \\ ${ }^{2}$ Department of Agriculture, Food, Environment and Forestry, University of Florence, Via San Bonaventura, 13 - 50145 Florence, Italy \\ ${ }^{3}$ Biotechnical Faculty, Department of Animal Science, University of Ljubljana, Groblje 3, 1230 Domžale, Slovenia
}

\section{ABSTRACT}

The bedding material used in barns for dairy cows has a significant effect on animal welfare and performance. Bedding influences the duration in which animals remain lying down and, consequently, the processes of rumination and milk production. It is crucial to have a complete understanding of the properties of bedding materials and the effects of alternative bedding materials on dairy cattle. This paper aims to evaluate the physical, chemical, and biological properties of various alternative and conventional bedding materials for dairy cattle for use in compost bedded pack or freestall barn systems. We analyzed 50 samples of 17 bedding materials produced in 3 European countries. We analyzed physical properties including the water holding capacity, porosity, moisture content, bulk density, dry bulk density, and particle size. Chemical analyses were performed to determine the total $\mathrm{N}$, total organic $\mathrm{C}$, and C:N ratio. In the biological analyses, the Escherichia coli count, total bacteria count, coliform count, and Klebsiella spp. count were assessed. The results demonstrated how the physical properties of the bedding materials may influence the chemical and biological properties. All of the materials presented adequate chemical properties to be used as bedding material. The physical properties of the bedding materials differed widely among the materials except for the dry bulk density, which presented no difference. Moreover, the contamination of each studied microorganism was observed for each bedding material to determine which material had the lowest level of contamination. Posidonia oceanica, Miscanthus grass, and spelt husks could be considered as a potential alternative material for use as bedding material for dairy cows in both systems (i.e., composted bedded pack and freestall). This ex-

Received February 5, 2020.

Accepted May 11, 2020.

*Corresponding author: patricia.ponciano@ufla.br periment illustrated the importance of performing thorough physical, chemical, and biological analyses before implementing a material as bedding for dairy cattle. Key words: dairy cow, compost bedded pack barn, free stall barn

\section{INTRODUCTION}

Dairy cattle usually prioritize resting over other behaviors (Munksgaard et al., 2005; Norring et al., 2008); they generally spend 8 to $16 \mathrm{~h} / \mathrm{d}$ lying down (Tucker et al., 2009). The duration that cows spend lying down depends on the type of bedding material provided, among other factors. Cows prefer to spend more time lying down when the bedding is deep, soft, and dry (Tucker and Weary, 2004; Tucker et al., 2009; Reich et al., 2010). Additionally, there is clear evidence that proper bedding management plays an important role in increasing the productivity of dairy farms (Yajima et al., 2017).

Although some housing systems require little to no bedding, most dairy systems rely on an adequate supply of bedding materials to ensure the comfort and hygiene of cows. The main function of bedding is to provide a lying surface with thermal comfort and softness for the animals, as cows have been shown to spend more time lying down when stalls are soft and dry (Wolfe et al., 2018). Moreover, bedding must be durable and have sufficient friction to allow for rising and lying down without slipping (van Gastelen et al., 2011). Bedding material should also help to keep cows clean and healthy while minimizing daily labor requirements (Chaplin et al., 2000).

In bedded pack barns - including conventional straw yards and compost bedded pack (CBP) barns - cows walk, stand, and lie over the bedded pack. These systems generally require a relatively large amount of bedding materials to absorb the moisture contained in cattle excreta, which are deposited over the bedding (Bewley et al., 2017). In addition to providing a dry and soft surface for the cows to rest, bedding material 
used in bedded pack barns needs adequate bearing capacity to support the weight of the cows during walking (Leso et al., 2020).

In contrast, in freestall (FS) barns with cubicles, cows mainly defecate and urinate outside of the resting area, and thus adequate hygiene can be maintained with relatively small amounts of bedding materials (Bewley et al., 2017). Furthermore, as cows do not need to walk over the bedded area, the weight bearing capacity of bedding materials is less of a concern in FS barns.

The efficiency of a specific bedding material is determined by many factors, such as particle size (PS) and its water holding capacity (WHC), reduce moisture content (MC), and alleviate caking (Kheravii et al., 2017). According to Agnew and Leonard (2003), an accurate evaluation of the physical properties of bedding material is essential for predicting appropriate handling, storage, treatment, disposal, and cost. In dairy systems, an appropriate chemical substrate must be maintained in the bedding to promote aerobic microbial activity, especially in a CBP barn (Black et al., 2013). When cows lay down, their teats may come in direct contact with bacteria in the bedding (Cook et al., 2005; Hogan and Smith, 2012).

The ability of bedding to support bacterial growth varies between bedding type, and could be dependent upon the physical, biochemical, and nutritional properties of the bedding (Godden et al., 2008). Inorganic materials, such as sand, do not support bacterial growth, and can therefore reduce the risk of mastitis (Bewley et al., 2017). Organic bedding materials could result in a higher risk of mastitis. However, the resulting manure is easier to handle when using organic bedding and can positively affect soil fertility as a result of higher amounts of OM. Furthermore, in other housing systems, such as CBP, an appropriate chemical substrate must be maintained in the bedding to promote aerobic microbial activity, which forms the basis of the composting process (Black et al., 2013). Regardless of the housing system used, the compostability of bedding materials is a desirable characteristic, as composted manure has been shown to improve soil fertility and could potentially reduce the environmental impact of dairy systems (Leso et al., 2020).

The most commonly used bedding materials in cow housing systems are sawdust, wood shavings, and sand (Janni et al., 2007; Lybæk and Kjaer, 2019; Oliveira et al., 2019). Other materials, including straw, peanut shells, and woodchips (Galama, 2014; Fávero et al., 2015; Leso et al., 2018; Leso et al., 2020), are also commonly used as bedding material. Oliveira et al. (2019) and Yajima et al. (2017) reported a growing demand for bedding materials, particularly sawdust and wheat straw. This demand has driven up prices, pushing farmers to look for alternative bedding materials. However, it is crucial to have a complete understanding of the nature of these alternative materials and their characteristics with regard to their use and handling as bedding materials (Agnew and Leonard, 2003).

Thus, the present study aimed to evaluate the physical, chemical, and biological properties of conventional and alternative bedding materials for dairy cattle in CBP or FS barn systems. Furthermore, this study aimed to present new potential alternative materials for use as bedding for dairy cattle.

\section{MATERIALS AND METHODS}

To analyze the physical, chemical, and biological properties of bedding materials for dairy cattle in different housing systems, 50 samples of 17 types of bedding materials were evaluated. Dairy cattle farmers from 3 European countries (Italy, the Netherlands, and Slovenia) selected the bedding materials to be evaluated according to the availability of these materials on their respective properties, thereby allowing the farmers to evaluate the potential of these materials for bedding. Initially, the farms sent us potential materials, which were subsequently selected and sampled according to the type of material (Table 1). The bedding samples were classified as alternative or conventional materials based on the number of related scientific papers found in the literature. These samples were collected from the 3 European countries, as shown in Table 1.

\section{Physical Property Analysis}

Physical property analyses of the materials were carried out at the Department of Agriculture, Food, Environment, and Forestry (DAGRI) of the University of Florence (UniFi), Italy. The physical properties we analyzed included the WHC, porosity (POR), MC, bulk density (BD), dry bulk density $\left(\mathbf{B D}_{\mathrm{dry}}\right)$, and PS.

The BD of the materials was determined according to ASAE Standard S269.4 DEC 91 (ASABE Standards, 2007), using 3 glass containers with a known volume. The material was poured into a container from a specific height to facilitate a free flow of the sample until the container overflowed. The combined weight of the material and the container was recorded, and the $\mathrm{BD}$ $\left(\mathrm{kg} \cdot \mathrm{m}^{-3}\right)$ was calculated using Equation 1:

$$
\mathrm{BD}=M / V
$$

where $M$ is the mass of the tested bedding material $(\mathrm{kg})$ and $V$ is the container volume $\left(\mathrm{m}^{3}\right)$. 
The methodology described by Dunlop et al. (2015) was adapted by following Standards Australia AS 3743-2003 (Appendix B Method in Standards Australia, 2003) to obtain the WHC, POR, and $\mathrm{BD}_{\mathrm{dry}}$.

The WHC was determined using Equation 2 to obtain results (in $\mathrm{kg} \cdot \mathrm{kg}^{-1}$ ):

$$
\mathrm{WHC}=\frac{\left(M_{w}-M_{d r y}\right)}{V_{b}} \times \mathrm{BD},
$$

where $M_{w}$ is the mass of the saturated material $(\mathrm{kg})$, $M_{d r y}$ is the dry mass of the material $(\mathrm{kg}), V_{b}$ is the volume of the recipient material $\left(\mathrm{m}^{-3}\right)$, and $\mathrm{BD}$ is the bulk density $\left(\mathrm{kg} \cdot \mathrm{m}^{-3}\right)$.

The POR (\%) was calculated from Equation 3:

$$
\mathrm{POR}=\frac{V_{\text {drained }}}{V_{b}} \times 100
$$

where $V_{\text {drained }}$ is the volume of water drained from the material (L) and $V_{b}$ is the volume of the recipient material $(\mathrm{L})$.

The $\mathrm{BD}_{d r y}$ can be obtained from Equation 4:

$$
\mathrm{BD}_{d r y}=\frac{m_{d r y}}{V_{b}}
$$

where $m_{d r y}$ is the mass of the dried material $(\mathrm{kg})$ and $V_{b}$ is the volume of the sample $\left(\mathrm{m}^{-3}\right)$.
The initial moisture of the material obtained from the field was determined using a moisture balance (WPS 50SX-1; accuracy of $0.001 \mathrm{~g} / 0.01 \%$ ).

The PS was determined according to the methodology proposed by Jobim et al. (2007). A 50-g sample was successively applied to a set of 6 meshes (50-, 16-, 8-, 4-, 2-, and 0.425-mm and bottom) and shaken 5 times at each horizontal $90^{\circ}$ angle; this process was then repeated for a total of 40 shakes. After the shaking process, each mesh and the remaining material were weighed, and the PS was calculated. Moreover, the largest particles remaining in the $50-\mathrm{mm}$ mesh were measured by a caliper, and the smallest particles remained at the bottom. Analyses of physical properties were carried out in 3 replicates for each type of bedding sample. The average of the results for each sample was used for analyses.

\section{Chemical and Biological Property Analyses}

Chemical and biological analyses were performed at the MADE HSE Laboratory located in Mantua, Italy. The chemical analyses included an assessment of the total $\mathrm{N}$ following the MI mep-c-62 (Kjeldahl) method, total organic carbon (TOC) following UNI EN 13137:2002, and the C:N ratio following the MI mep-c-41 calculation method.

The biological analyses included an Escherichia coli count following the MI mep-m-32 method, a total bacteria count (TBC) following the MI mep-m-26 method, a coliform count following the MI mep-m-32 method, and a Klebsiella spp. count following the PT 332 NA-

Table 1. Bedding materials and their country of origin

\begin{tabular}{lcll}
\hline Material & $\begin{array}{c}\text { Number } \\
\text { of samples }\end{array}$ & Country of origin & Classification \\
\hline Barley husks & 2 & The Netherlands & Alternative \\
Bark mulch & 2 & The Netherlands & Alternative \\
Barley straw & 3 & Italy (1), the Netherlands (1), and Slovenia (1) & Conventional \\
Conifer forest litter & 1 & Italy & Alternative \\
Dried sawdust & 6 & Italy (5) and Slovenia (1) & Conventional \\
Fresh sawdust & 2 & Italy (1) and Slovenia (1) & Conventional \\
Flax straw & 3 & Slovenia & Alternative \\
Hemp straw & 3 & Slovenia & Alternative \\
Miscanthus grass & 3 & Italy (1), the Netherlands (1), and Slovenia (1) & Alternative \\
Posidonia oceanica & 1 & Italy & Alternative \\
Spelt husks & 3 & Slovenia & Alternative \\
Triticale husks & 2 & Slovenia & Alternative \\
Triticale straw & 1 & Italy & Conventional \\
Wood chips & 6 & Italy (2), the Netherlands (1) and Slovenia (3) & Conventional \\
Wheat husks & 2 & Slovenia & Alternative \\
Wood shavings & 3 & Italy (1) and Slovenia (2) & Conventional \\
Wheat straw & 7 & Italy (2) and Slovenia (5) & Conventional \\
\hline
\end{tabular}


Terreno McConkey method. Chemical and biological analyses were performed once for each type of bedding sample.

\section{Data Analyses}

Statistical Analyses. One-way ANOVA was performed to assess the effect of the material type on the response variables. The experimental unit was the sample of bedding material. Sources of variability resulted from different samples within each type of bedding material. Bacterial concentrations were log-transformed before analysis. When a significant effect was found, the Scott-Knot test was used to determine differences between means, and differences were determined to be statistically significant at $P \leq 0.05$. Analyses were performed using R software (R Development Core Team, 2019).

Cluster Heat Map. According to Wilkinson and Friendly (2009), a cluster heat map can simultaneously reveal row and column hierarchical cluster structures in a data matrix. This map consists of a rectangular tiling, with each tile shaded on a color scale to represent the value of the corresponding element of the data matrix. The rows (columns) of the tiling are ordered such that similar rows (columns) are near each other, with hierarchical cluster trees on the vertical and horizontal margins of the tiling (Wilkinson and Friendly, 2009).

Hierarchical agglomerative clustering analysis is a simple and effective method for evaluating similarities among data based on the idea of grouping objects that are similar according to some predetermined criteria (Linden, 2009). Hierarchical clustering analysis (HCA) involves calculating the distance matrices of data objects and then merging objects that are close to each other to form sub-clusters. This approach was used to interpret the PS distribution for each type of bedding material. Similar objects are grouped within clusters, whereas objects that differ are grouped into different clusters (Dominick et al., 2012).

In the present study, the relative levels of each PS were determined, and then, all data were z-score transformed to produce a heat map using a supervised HCA method, as described by Ferraz et al. (2014). The clustering method and similarity measure were set as the unweighted average and Euclidean distance, respectively.

The Euclidean distance (ED; Equation 5) is based on a single binding (also known as a nearest neighbor), given as the connection or linkage distance $\left(\mathrm{D}_{\text {link }}\right)$ divided by the maximum distance $\left(\mathrm{D}_{\max }\right.$; Dominick et al., 2012):

$$
\mathrm{ED}=\frac{\mathrm{D}_{\text {link }}}{\mathrm{D}_{\max }} \times 100
$$

As the initial cluster, the Ward method considers individuals who provide the lowest sum of squares of deviations (Melo Júnior et al., 2006). The PS is represented by colors in the heat map, illustrated as a single row of colored boxes, whereas columns represent different bedding materials. In the $\mathrm{R}$ statistical software ( $\mathrm{R}$ Development Core Team, 2019), library gplots was used to develop the cluster heat map.

Free Viz Analysis. FreeViz is an intelligent multivariate visualization approach, as described by Demšar et al. $(2005,2007)$. According to these authors, FreeViz is an optimization method that finds a linear projection and an associated scatterplot that best separates instances of different classes. Using a single graph, the resulting FreeViz visualization can provide a global view of the classification problem being studied, reveal interesting relations between classes and features, uncover feature interactions, and provide information about intra-class similarities. The mathematical foundations of FreeViz have been presented in previous work, with a report on its utility for various biomedical data sets. Demšar et al. (2007) presented the mathematical foundations of FreeViz, explained the optimization method, and described its utility for various data sets. In the current study, a FreeViz analysis was applied to the biological counts of the different bedding materials. Orange Canvas (Demšar, and Zupan, 2013) was used to develop the FreeViz analysis.

\section{RESULTS AND DISCUSSION}

Physical properties are key features in the characterization of bedding materials. In Table 2, the physical properties of the evaluated bedding materials are shown.

According to Dunlop et al. (2015), the WHC is an important characteristic of bedding materials because it indicates the amount of water that can be absorbed and stored. Eckelkamp et al. (2016) stated that the WHC refers to the amount of water held in the material, which is influenced by the OM content, texture, and structure of the material. The alternative bedding material Posidonia oceanica presented the highest WHC (Table 2), whereas wood shavings and barley straw, which are both conventional bedding materials, presented an intermediate WHC. The other materials presented similarly low values.

In this experiment, bark mulch, an alternative bedding material, presented the highest $\mathrm{MC}$ value 
Table 2. Average water holding capacity (WHC), moisture content (MC), porosity (POR), bulk density (BD), and dry bulk density $\left(\mathrm{BD}_{d r y}\right)$ of the bedding materials

\begin{tabular}{|c|c|c|c|c|c|}
\hline Material & $\underset{\left(\mathrm{kg} \cdot \mathrm{kg}^{-1}\right)}{\mathrm{WHC}}$ & $\begin{array}{l}\mathrm{MC} \\
(\%)\end{array}$ & $\begin{array}{c}\text { POR } \\
(\%)\end{array}$ & $\frac{\mathrm{BD}}{\left(\mathrm{kg} \cdot \mathrm{m}^{-3}\right)}$ & $\underset{\left(\mathrm{kg} \cdot \mathrm{m}^{-\underline{3}}\right)}{\mathrm{BD}_{\text {dry }}}$ \\
\hline Barley husks & $1.62^{\mathrm{c}}$ & $9.64^{\mathrm{c}}$ & $63.81^{\mathrm{a}}$ & $136.65^{\mathrm{c}}$ & $101.60^{\mathrm{a}}$ \\
\hline Bark mulch & $0.65^{\mathrm{c}}$ & $61.95^{\mathrm{a}}$ & $61.01^{\mathrm{a}}$ & $369.27^{\mathrm{a}}$ & $141.85^{\mathrm{a}}$ \\
\hline Barley straw & $4.13^{\mathrm{b}}$ & $9.80^{\mathrm{c}}$ & $83.04^{\mathrm{a}}$ & $26.30^{\mathrm{c}}$ & $26.41^{\mathrm{a}}$ \\
\hline Conifer forest litter & $0.78^{\mathrm{c}}$ & $12.27^{\mathrm{c}}$ & $79.91^{\mathrm{a}}$ & $123.01^{\mathrm{c}}$ & $82.98^{\mathrm{a}}$ \\
\hline Dried sawdust & $3.19^{\mathrm{c}}$ & $10.99^{\mathrm{c}}$ & $23.41^{\mathrm{b}}$ & $224.86^{\mathrm{b}}$ & $178.61^{\mathrm{a}}$ \\
\hline Fresh sawdust & $2.08^{\mathrm{c}}$ & $43.72^{\mathrm{b}}$ & $33.12^{\mathrm{b}}$ & $236.10^{\mathrm{b}}$ & $138.65^{\mathrm{a}}$ \\
\hline Flax straw & $2.45^{\mathrm{c}}$ & $9.42^{\mathrm{c}}$ & $69.18^{\mathrm{a}}$ & $71.55^{\mathrm{c}}$ & $50.57^{\mathrm{a}}$ \\
\hline Hemp straw & $1.66^{\mathrm{c}}$ & $10.17^{\mathrm{c}}$ & $79.61^{\mathrm{a}}$ & $72.33^{\mathrm{c}}$ & $51.61^{\mathrm{a}}$ \\
\hline Miscanthus grass & $2.31^{\mathrm{c}}$ & $15.27^{\mathrm{c}}$ & $64.28^{\mathrm{a}}$ & $90.60^{\mathrm{c}}$ & $83.03^{\mathrm{a}}$ \\
\hline Posidonia oceanica & $7.32^{\mathrm{a}}$ & $13.16^{\mathrm{c}}$ & $71.49^{\mathrm{a}}$ & $30.90^{\mathrm{c}}$ & $41.47^{\mathrm{a}}$ \\
\hline Spelt husks & $1.65^{\mathrm{c}}$ & $11.51^{\mathrm{c}}$ & $63.69^{\mathrm{a}}$ & $96.91^{\mathrm{c}}$ & $78.28^{\mathrm{a}}$ \\
\hline Triticale husks & $2.92^{\mathrm{c}}$ & $10.57^{\mathrm{c}}$ & $85.40^{\mathrm{a}}$ & $28.88^{\mathrm{c}}$ & $21.42^{\mathrm{a}}$ \\
\hline Triticale straw & $2.90^{\mathrm{c}}$ & $10.02^{\mathrm{c}}$ & $89.85^{\mathrm{a}}$ & $19.60^{\mathrm{c}}$ & $16.76^{\mathrm{a}}$ \\
\hline Wood chips & $1.29^{\mathrm{c}}$ & $12.82^{\mathrm{c}}$ & $61.35^{\mathrm{a}}$ & $178.34^{\mathrm{b}}$ & $138.09^{\mathrm{a}}$ \\
\hline Wheat husks & $2.95^{\mathrm{c}}$ & $9.07^{\mathrm{c}}$ & $82.66^{\mathrm{a}}$ & $36.44^{\mathrm{c}}$ & $28.54^{\mathrm{a}}$ \\
\hline Wood shavings & $4.89^{\mathrm{b}}$ & $10.09^{c}$ & $52.28^{\mathrm{b}}$ & $86.85^{\mathrm{c}}$ & $74.10^{\mathrm{a}}$ \\
\hline Wheat straw & $3.32^{\mathrm{c}}$ & $9.33^{\mathrm{c}}$ & $79.35^{\mathrm{a}}$ & $33.13^{\mathrm{c}}$ & $38.40^{\mathrm{a}}$ \\
\hline$P$-value & $<0.05$ & $<0.05$ & $<0.05$ & $<0.05$ & $<0.05$ \\
\hline
\end{tabular}

${ }^{\mathrm{a}-\mathrm{c}}$ Averages followed by the same superscript letter in each column are not statistically different based on the Scott-Knot test at 5\% significance.

(61.95\%), followed by fresh sawdust (43.72\%), a conventional bedding material. The other materials presented MC values of 9.07 to $15.27 \%$. Adequate moisture is necessary to support microbial activity. According to Tchobanoglous et al. (1993), the optimum range that is generally recommended for composting is 50 to $60 \%$. However, Liang et al. (2003) reported that maximum microbial activities were obtained for $\mathrm{MC}$ values in the range of 60 to $70 \%$. According to Keys et al. (1976) and Fregonesi et al. (2007), cows prefer low- over high-moisture bedding in both winter and summer. The authors also reported that cattle avoid lying on surfaces with high MC. To avoid health problems, such as mastitis, Zehner et al. (1986) recommended that bedding materials for FS be kept as clean and dry as possible to limit bacterial inoculation and growth. For a CBP, the initial moisture of the bedding materials is important. According to Janni et al. (2007), adequate ventilation (air exchange) is necessary for this kind of barn to remove the heat and moisture generated by the biologically active pack. Thus, it is not desirable to use bedding material with a high-moisture value because energy will then be required to dry the bed. Therefore, the use of materials that present high $\mathrm{MC}$ values, such as fresh sawdust (conventional) and bark mulch (alternative), is not feasible. Moreover, the bedding materials of CBP must be frequently turned. The MC of the bedding at the time of compaction also influences the amount of energy required to break up a piece of compacted material once it has dried (Dunlop et al., 2016). Bernhart et al. (2010) reported that the force required to break compacted samples of bedding in- creases substantially when the MC is higher at the time of compaction. Moreover, Ahn et al. (2008) reported that moisture promotes the aggregation of particles and reduces POR.

The degree of porosity of the bedding material is an important factor in the adsorption of microorganisms. Bedding material with a large interior void space allows microorganisms to attach under low shear conditions, and the fluid outside of the bedding material can move at high speeds (Cohen, 2001). The values of POR for the dried sawdust, fresh sawdust, and wood shavings were the lowest, whereas the other materials presented statistically equivalent values.

The BD is an important characteristic of bedding material. Agnew and Leonard (2003) showed that higher BD values imply an increase in mass and a decrease in POR and air volume. These authors also reported that the $\mathrm{BD}$ of a given bedding material is often considered in calculations of storage design and transportation, and also in determining the power requirements for operations such as turning and mixing of the bedding. The highest BD value was exhibited by bark mulch, an alternative material, followed by dried sawdust and fresh sawdust. According to Michel et al. (2004), materials with small PS and high BD values experience lower reductions in volume over time, which may be the case for dried and fresh sawdust.

The $\mathrm{BD}_{\text {dry }}$ value is the $\mathrm{BD}$ under water-saturated conditions, which enables a more thorough comparison of the materials. In this experiment, all of the materials exhibited statistically equivalent values under conditions of saturation. 
Based on the physical properties, the alternative bedding material $P$. oceanica is notable because it presented the largest WHC value. Additionally, this material exhibited physical properties similar to those of the conventional materials evaluated. Bark mulch had the highest $\mathrm{MC}$ and $\mathrm{BD}$ values, which are not desirable for bedding material. For POR and $\mathrm{BD}_{\text {dry }}$, the alternative bedding materials presented values similar to those of the majority of the conventional bedding materials studied.

The different bedding materials were analyzed to determine the PS distributions via a hierarchically clustered heat map (Figure 1). Heat maps are visual representations of quantitative data on 2 axes; the $\mathrm{x}$ axis represents the groups based on PS, and the y-axis consists of the bedding materials. The field between the axes comprises an array of contiguous boxes that are color coded to reflect the corresponding quantities (Moon et al., 2009). This method can also be used to visualize the quantitative amount (\%) of particles in each evaluated size. One significant advantage of the heat map is its ability to portray the bedding material PS, which allows patterns to be easily identified. In Figure 1, red represents high concentrations and green represents low concentrations of particles.
Figure 1 shows that the bedding materials were hierarchically clustered in 4 large clusters based on the PS fraction. The first cluster is composed of the straw samples (hemp, wheat, barley, triticale, flex) and Miscanthus. Thus, based on this cluster analysis, regardless of the straw type (conventional or alternative), all straw samples presented a similar PS. In addition, this cluster primarily consists of particles larger than $50 \mathrm{~mm}$. Miscanthus is unique in this cluster because it presents a high concentration of particles larger than $50 \mathrm{~mm}$, as well as a considerable number of particles between 4 and $8 \mathrm{~mm}$.

The 2 sawdust samples (dried and fresh) are included in the second cluster, but no alternative bedding material exhibited this PS. In both sawdust samples, the greatest fraction corresponded to particle sizes between 0.425 and $2 \mathrm{~mm}$, representing almost $60 \%$ of the sawdust particles. Thus, this cluster can be considered to have the lowest PS. According to Nakasaki et al. (1986), materials with a higher proportion of small particles should be more desirable for compost materials because microorganisms primarily grow on particle surfaces. In addition, as bedding needs to be cultivated frequently in CBP barns, the authors suggested selecting materials with a maximum PS of $25 \mathrm{~mm}$ for use in this type

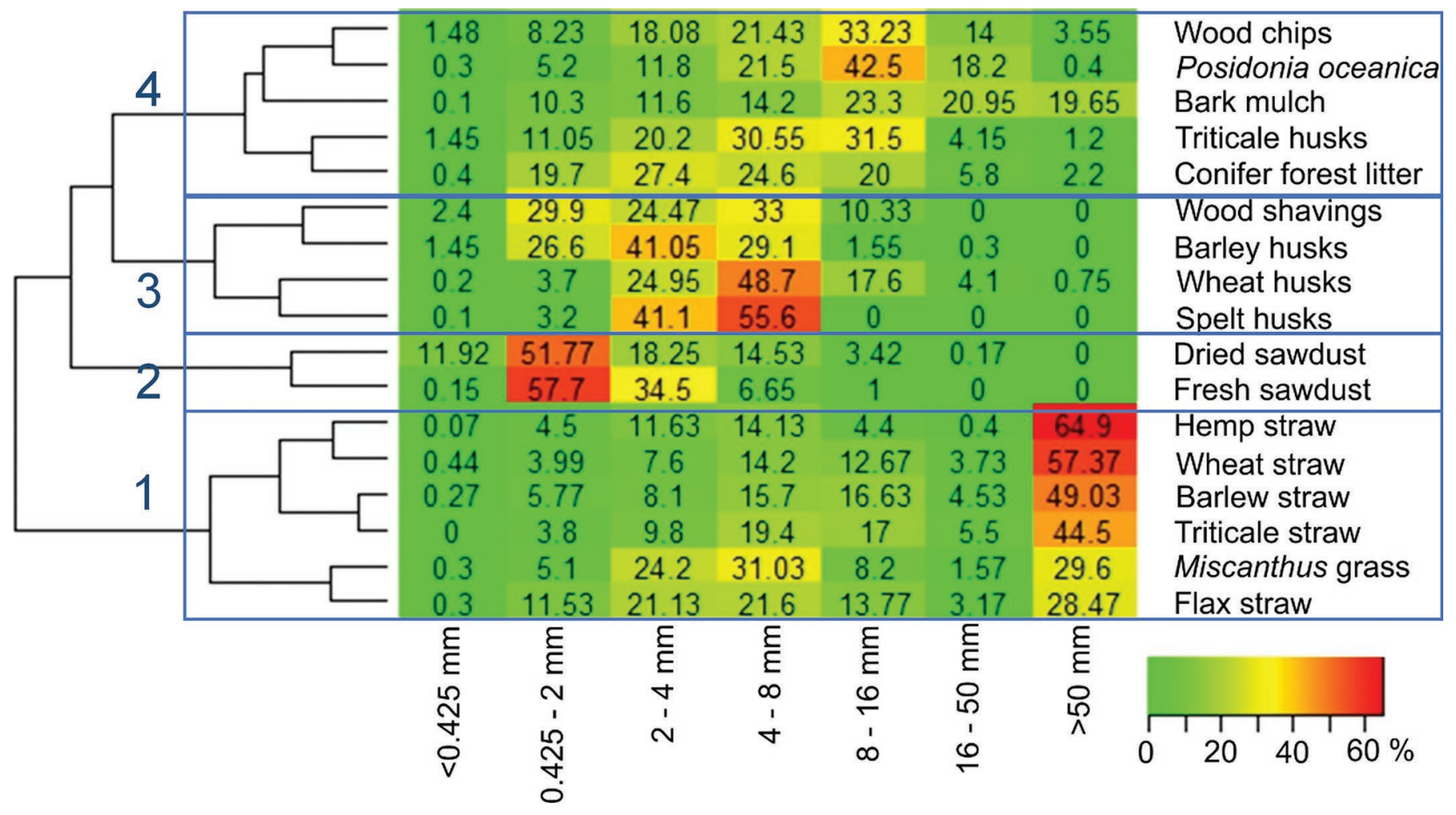

Figure 1. Hierarchically clustered heat map of the particle size distribution of all bedding materials evaluated. The blue rectangles indicate the 4 hierarchical clusters $(1,2,3,4)$. 
of housing system (Shane et al., 2010). Materials with larger particles should be processed to less than $25 \mathrm{~mm}$ before being used in a CBP barn. For these reasons, fine materials are generally preferred for systems that rely on composting. On the other hand, if a material is too fine, it can be too easily compacted (Agnew and Leonard, 2003). In this case, the pore space can become very small, thereby limiting oxygen availability in the bedded pack, and in turn inhibiting the composting process. Thus, selecting materials with an adequate PS is particularly important in bedded pack systems, although some of the aforementioned concepts also apply to FS housing systems. Finally, another factor that should be considered in relation to PS is the production of dust. According to Samadi et al. (2012), high concentrations of fine particles should be avoided regardless of the housing system material used, as bedding has a strong influence on the level of dust in dairy barns. Of the materials analyzed in the current study, dried sawdust exhibited the highest content of fine particles $(<0.425 \mathrm{~mm})$, which indicated the potential for high levels of dust.

The third and fourth clusters presented intermediate PS, lying between the first and second clusters. The third cluster consists of bedding materials with a medium-sized fraction, primarily containing particles of 2 to $8 \mathrm{~mm}$. This cluster includes husk samples (barley, wheat, and spelt), which are alternative bedding materials, and wood shavings, which are conventional bedding materials (Smith et al., 2017; Albino et al., 2018; Ahn et al., 2020). Notably, more than $96 \%$ of the spelt husk particles fall in this interval. Wheat husk is unique in this cluster because it presents particles larger than $50 \mathrm{~mm}$.

The fourth cluster is composed of materials with particle sizes of 4 to $16 \mathrm{~mm}$. The conventional material in this group is wood chips (Van Dooren et al., 2016; Smith et al., 2017; Van Dooren et al., 2018), and the alternative bedding materials include bark mulch, conifer forest litter, $P$. oceanica, and triticale husks. In this group, $42 \%$ of the $P$. oceanica particles were in the size range of 8 to $16 \mathrm{~mm}$.

Based on this HCA, clusters 1,3 , and 4 were composed of both conventional and alternative bedding materials. This grouping enables a comparison of the material types and can facilitate choices among these materials.

The average chemical parameters of the bedding materials are shown in Table 3. Barley husks and conifer forest litter, which are alternative bedding materials, presented the highest total $\mathrm{N}$ values. All of the studied materials had statistically equivalent TOC values, except $P$. oceanica $(322.0 \mathrm{~g} / \mathrm{kg})$, which presented the lowest value. The $\mathrm{C}$ content determines the amount of $\mathrm{N}$ that can be immobilized during decomposition (Kirchmann, 1985; Kirchmann and Witter, 1989). In a CBP, a high $\mathrm{C}$ content is desirable because microbes require $\mathrm{C}$ for the synthesis of cell material and energy; moreover, microbes require $\mathrm{N}$ to build cell proteins and other N-containing cell materials (Kirchmann 1985; Kirchmann and Witter, 1989). Hence, according to these authors, the addition of C-rich organic materials to manure allows more ammonium to be biologically immobilized during decomposition.

The conventional bedding materials (wood shavings, dried sawdust, and fresh sawdust) presented the highest C:N ratios. According to Jeppsson (1999), microbes use 30 parts of $\mathrm{C}$ for 1 part of $\mathrm{N}$ (on average). In this experiment, all of the materials presented C:N ratios exceeding 39.5, which is desirable. Poincelot (1974) stated that when the C:N ratio is below 26, the excess $\mathrm{N}$ is lost in the atmosphere as ammonia. Kirchmann (1985) reported that no ammonia $\mathrm{N}$ losses occur for $\mathrm{C}: \mathrm{N}$ ratios above 50 . Only the alternative bedding material barley husks presented a C:N ratio smaller than 50 . The other evaluated material will not lose ammonia $\mathrm{N}$ because their C:N ratios are greater than 50.

Table 3 shows that the conventional and alternative materials are very similar, with the exception of barley husks (an alternative material), due to their high total $\mathrm{N}$ value and low $\mathrm{C}: \mathrm{N}$ ratio. Although $P$. oceanica presented the lowest TOC value, it presented a satisfactory $\mathrm{C}: \mathrm{N}$ ratio according to the minimum proposed by Kirchmann (1985). Studies on the composting process have indicated that $\mathrm{OM}$ degrades faster when the $\mathrm{C}: \mathrm{N}$

Table 3. Average total N, total organic C (TOC), and C:N ratio for the evaluated bedding materials

\begin{tabular}{lccc}
\hline Material & $\begin{array}{c}\text { Total N } \\
(\%)\end{array}$ & $\begin{array}{c}\text { TOC } \\
(\mathrm{g} / \mathrm{kg})\end{array}$ & $\begin{array}{r}\text { C:N } \\
\text { ratio }\end{array}$ \\
\hline Barley husks & $1.2^{\mathrm{a}}$ & $476.0^{\mathrm{a}}$ & $39.5^{\mathrm{b}}$ \\
Bark mulch & $0.5^{\mathrm{b}}$ & $537.0^{\mathrm{a}}$ & $111.0^{\mathrm{b}}$ \\
Barley straw & $0.6^{\mathrm{b}}$ & $551.0^{\mathrm{a}}$ & $96.3^{\mathrm{b}}$ \\
Conifer forest litter & $0.9^{\mathrm{a}}$ & $555.0^{\mathrm{a}}$ & $62.0^{\mathrm{b}}$ \\
Dried sawdust & $0.1^{\mathrm{b}}$ & $537.2^{\mathrm{a}}$ & $478.5^{\mathrm{a}}$ \\
Fresh sawdust & $0.1^{\mathrm{b}}$ & $548.5^{\mathrm{a}}$ & $548.5^{\mathrm{a}}$ \\
Flax straw & $0.5^{\mathrm{b}}$ & $510.7^{\mathrm{a}}$ & $102.0^{\mathrm{b}}$ \\
Hemp straw & $0.6^{\mathrm{b}}$ & $496.3^{\mathrm{a}}$ & $98.7^{\mathrm{b}}$ \\
Miscanthus grass & $0.4^{\mathrm{b}}$ & $515.3^{\mathrm{a}}$ & $169.0^{\mathrm{b}}$ \\
Posidonia oceanica & $0.6^{\mathrm{b}}$ & $322.0^{\mathrm{b}}$ & $54.0^{\mathrm{b}}$ \\
Spelt husks & $0.6^{\mathrm{b}}$ & $504.7^{\mathrm{a}}$ & $85.3^{\mathrm{b}}$ \\
Triticale husks & $0.5^{\mathrm{b}}$ & $483.0^{\mathrm{a}}$ & $109.0^{\mathrm{b}}$ \\
Triticale straw & $0.3^{\mathrm{b}}$ & $473.0^{\mathrm{a}}$ & $158.0^{\mathrm{b}}$ \\
Wood chips & $0.3^{\mathrm{b}}$ & $544.3^{\mathrm{a}}$ & $349.8^{\mathrm{a}}$ \\
Wheat husks & $0.4^{\mathrm{b}}$ & $506.5^{\mathrm{a}}$ & $127.0^{\mathrm{b}}$ \\
Wood shavings & $0.4^{\mathrm{b}}$ & $536.7^{\mathrm{a}}$ & $292.3^{\mathrm{a}}$ \\
Wheat straw & $0.5^{\mathrm{b}}$ & $496.0^{\mathrm{a}}$ & $94.0^{\mathrm{b}}$ \\
P-value & $<0.05$ & $<0.05$ & $<0.05$ \\
\hline
\end{tabular}

${ }^{a, b}$ Averages followed by the same superscript letter in each column are not statistically different based on the Scott-Knot test at 5\% significance. 
Table 4. Average total bacteria count (TBC), Escherichia coli count (Ecc), coliform count (Cc), and Klebsiella spp. count $(\mathrm{Kc})$ for the 17 materials evaluated

\begin{tabular}{|c|c|c|c|c|}
\hline Material & $\begin{array}{l}\text { TBC } \\
(\mathrm{cfu} / \mathrm{g})\end{array}$ & $\begin{array}{c}\text { Ecc } \\
(\mathrm{cfu} / \mathrm{g})\end{array}$ & $\begin{array}{c}\mathrm{Cc} \\
(\mathrm{cfu} / \mathrm{g})\end{array}$ & $\begin{array}{c}\mathrm{Kc} \\
(\mathrm{cfu} / \mathrm{g})\end{array}$ \\
\hline Barley husks & $11,300,000.0$ & $110.0^{\mathrm{b}}$ & $710,000.0^{\mathrm{a}}$ & $0.0^{\mathrm{b}}$ \\
\hline Bark mulch & $9,450,000.0$ & $0.0^{\mathrm{b}}$ & $225,210.0^{\mathrm{a}}$ & $0.0^{\mathrm{b}}$ \\
\hline Barley straw & $14,066,666.7$ & $0.0^{\mathrm{b}}$ & $80,333.3^{\mathrm{a}}$ & $0.0^{\mathrm{b}}$ \\
\hline Conifer forest litter & $300,000.0$ & $1,100.0^{\mathrm{a}}$ & $19,000.0^{\mathrm{a}}$ & $110,000.0^{\mathrm{a}}$ \\
\hline Dried sawdust & $8,483,333.3$ & $1,833.3^{\mathrm{a}}$ & $2,333.3^{\mathrm{b}}$ & $2,166.7^{\mathrm{b}}$ \\
\hline Fresh sawdust & $24,500,000.0$ & $10.0^{\mathrm{b}}$ & $380.0^{\mathrm{b}}$ & $200.0^{\mathrm{b}}$ \\
\hline Flax straw & $9,366,666.7$ & $0.0^{\mathrm{b}}$ & $199,600.0^{\mathrm{a}}$ & $28,666.7^{\mathrm{a}}$ \\
\hline Hemp straw & $3,826,000.0$ & $0.0^{\mathrm{b}}$ & $8,466.7^{\mathrm{a}}$ & $0.0^{\mathrm{b}}$ \\
\hline Miscanthus grass & $833,333.3$ & $0.0^{\mathrm{b}}$ & $182,033.3^{\mathrm{a}}$ & $500.0^{\mathrm{b}}$ \\
\hline Posidonia oceanica & $440,000.0$ & $0.0^{\mathrm{b}}$ & $30.0^{\mathrm{b}}$ & $0.0^{\mathrm{b}}$ \\
\hline Spelt husks & $700,000.0$ & $0.0^{\mathrm{b}}$ & $10,333 \cdot 3^{\mathrm{a}}$ & $1,633.3^{\mathrm{b}}$ \\
\hline Triticale husks & $14,000,000.0$ & $0.0^{\mathrm{b}}$ & $920,000.0^{\mathrm{a}}$ & $0.0^{\mathrm{b}}$ \\
\hline Triticale straw & $100,000.0$ & $0.0^{\mathrm{b}}$ & $0.0^{\mathrm{b}}$ & $0.0^{\mathrm{b}}$ \\
\hline Wood chips & $7,000,000.0$ & $81.7^{\mathrm{b}}$ & $5,533.3^{\mathrm{b}}$ & $0.0^{\mathrm{b}}$ \\
\hline Wheat husks & $12,900,000.0$ & $0.0^{\mathrm{b}}$ & $915,000.0^{\mathrm{b}}$ & $0.0^{\mathrm{b}}$ \\
\hline Wood shavings & $166,666.7$ & $0.0^{\mathrm{b}}$ & $0.0^{\mathrm{b}}$ & $133.3^{\mathrm{b}}$ \\
\hline Wheat straw & $1,400,000.0$ & $0.0^{\mathrm{b}}$ & $20,714.3^{\mathrm{b}}$ & $0.0^{\mathrm{b}}$ \\
\hline$P$-value & 0.7659 & $<0.05$ & $<0.05$ & $<0.05$ \\
\hline
\end{tabular}

${ }_{\mathrm{a}, \mathrm{b}}$ Averages followed by the same superscript letter in each column are not statistically different based on the Scott-Knot test at 5\% significance.

ratio is in the range of 25:1 to 30:1 (Misra et al., 2003). As dairy cow feces have a lower C:N ratio-ranging from 15:1 to 19:1 (Leonard, 2001) - the use of materials with high $\mathrm{C} N$ ratios could improve the compostability of bedding and the resulting manure. For this reason, the $\mathrm{C}: \mathrm{N}$ ratio of bedding materials is particularly important in CBP (Leso et al., 2020).

Table 4 presents the bacteria count statistical analysis of the evaluated bedding materials. Figure 2 (A and B) presents the FreeViz results of the biological counts of the bedding materials. The bedding materials were randomly divided into 2 figures to visualize the main contaminants for each bedding type. The FreeViz algorithm optimizes a linear projection and displays the projected data in a scatterplot. The target projection is found through a gradient optimization approach and aims to separate instances of different classes in classlabeled data (Demšar et al., 2007).

Figure 2 and Table 4 indicate which bacteria count is most relevant for each evaluated bedding material. Figure 2 shows the biological characteristics (i.e., bacterial counts) of each type of material. In addition, it is possible to see which of these characteristics exerts the greatest influence. Figure 2A highlights the high E. coli count and TBC values for dried sawdust, indicating that both of these biological characteristics are a potential concern when using this material. Wheat husks exhibit the highest level of coliform contamination (Table 4), as well as low counts of $\mathrm{K}$ (Figure 2A). Conifer forest litter exhibits the highest level of $\mathrm{K}$ contamination, as well as a lower level count of coliforms. Lastly, fresh sawdust has the highest level of TBC contamination.
Figure 2B shows that wood chips are contaminated by E. coli and TBC, while Miscanthus has a high count of coliforms. In addition, Barley straw exhibits a high count of TBC, and flax straw displays high values for both Klebsiella spp. and coliforms

Microorganisms that cause mastitis can be related to the environmental transmission of pathogens (Manasa et al., 2019). E coli and Klebsiella spp. are among the most common gram-negative bacteria and are associated with more than $40 \%$ of all cases of clinical mastitis (Schukken et al., 2011; Oliveira et al., 2013). Escherichia coli tends to be the most prevalent, whereas clinical mastitis caused by Klebsiella spp. tends to be the most severe (Gorden et al., 2018). Bedding materials are primary sources of exposure to environmental mastitis pathogens for bovine teats (Hogan et al., 1990). Bovine mastitis results in substantial economic losses, primarily due to reduced milk yield, decreased milk quality, higher production costs, medication costs, loss of milk during and shortly after treatment, loss of milking days, reduced milk prices, increased labor, and increased recruitment costs due to culling (Seegers et al., 2003; Cremonesi et al., 2006). Therefore, the presence of pathogens in raw material should be considered when selecting a bedding material.

In this experiment, the alternative bedding materials flax straw and conifer forest litter presented the highest Klebsiella spp. counts. The presence of Klebsiella spp. was also noted in alternative bedding materials such as Miscanthus and spelt husk, as well as in conventional materials such as dried sawdust, fresh sawdust, and wood shavings. The other materials did not 
present Klebsiella spp. With regard to E. coli, many of the materials evaluated in this study presented no contamination. Only barley husks and conifer forest litter, which are alternative materials, and dried sawdust and wood chips, which are conventional materials, showed contamination with this microorganism.

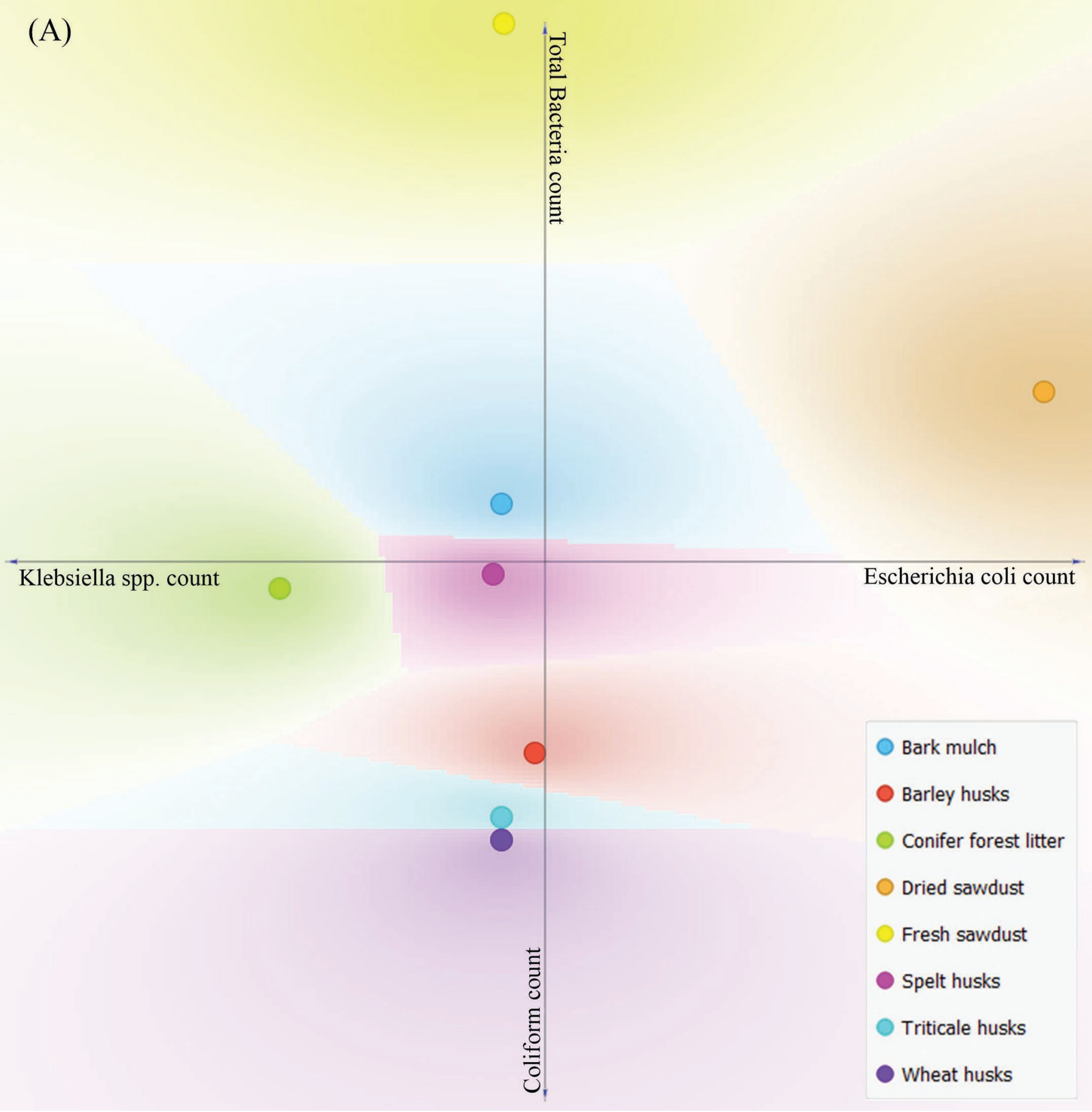

Figure 2. FreeViz (Demšar et al., 2005, 2007) optimization of the biological count for (A) bark mulch, barley husk, conifer forest litter, dried sawdust, fresh sawdust, spelt husks, triticale husks, and wheat husks and for (B) barley straw, flax straw, hemp straw, Miscanthus, Posidonia oceanica, triticale straw, wheat straw, wood chips and wood shavings. 


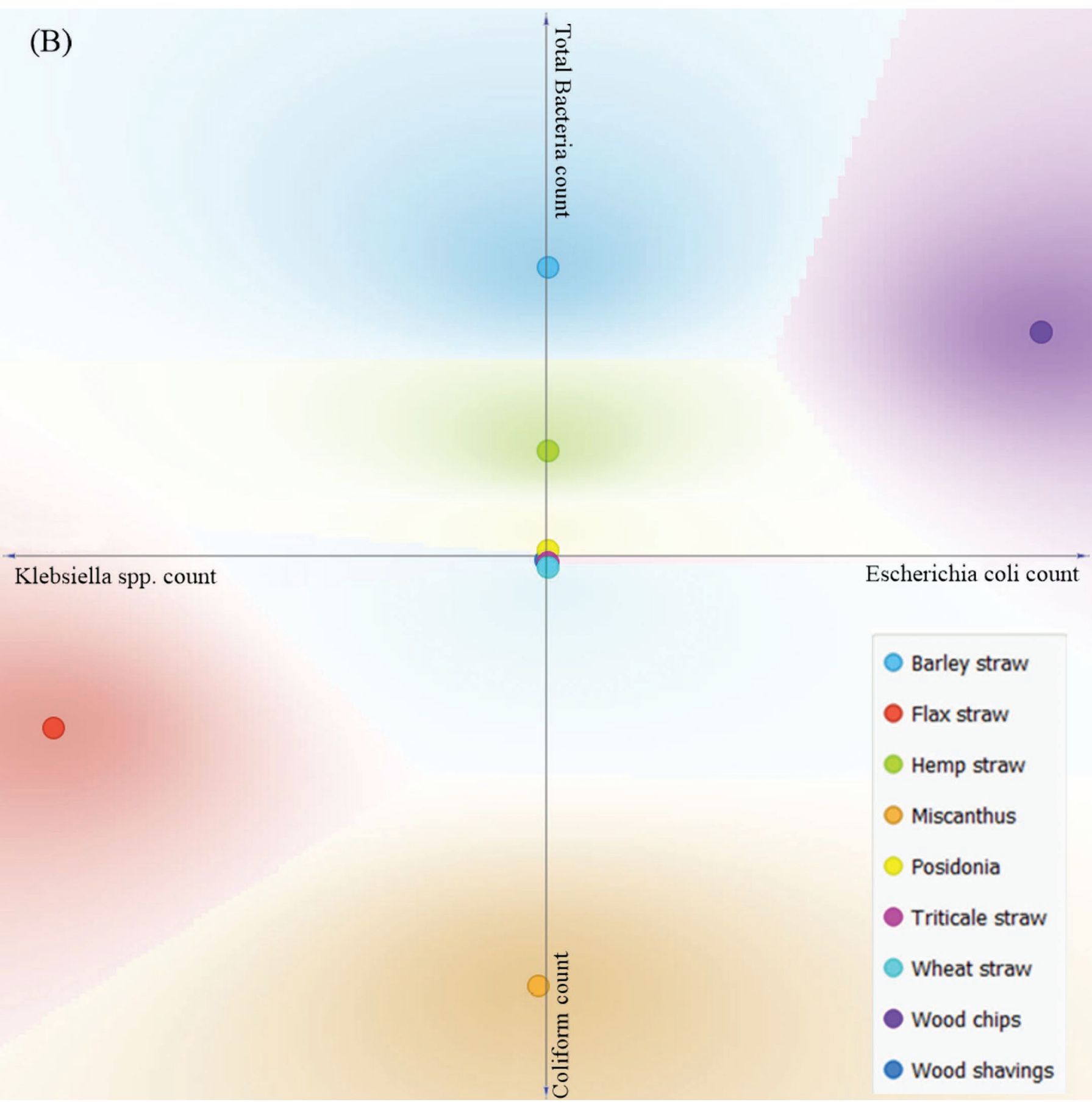

Figure 2 (Continued). FreeViz (Demšar et al., 2005, 2007) optimization of the biological count for (A) bark mulch, barley husk, conifer forest litter, dried sawdust, fresh sawdust, spelt husks, triticale husks, and wheat husks and for (B) barley straw, flax straw, hemp straw, Miscanthus, Posidonia oceanica, triticale straw, wheat straw, wood chips and wood shavings.

The TBC can be useful for estimating farm sanitation efficacy, overall udder health, and proper milk handling and storage temperatures (Hayes et al., 2001). Bramley and Neave (1975) stated that organic materials, such as straw and sawdust, often contain $>10^{6} \mathrm{cfu} / \mathrm{g}$ of coliform bacteria when used as bedding. Barley husks, bark mulch, flax straw, triticale husks, and wheat husks (alternative materials), as well as barley straw and fresh sawdust (which are conventional materials) presented the highest TBC values, exceeding $10^{6}$. 
According to Hogan and Smith (1997), sawdust and wood shavings are popular choices as bedding materials despite evidence that outbreaks of coliform mastitis within herds are commonly attributed to contaminated bedding. This study demonstrated that materials should be evaluated before being used as bedding for cows to reduce mastitis risk.

The microbiological contamination of bedding exerts different influences depending on the house system (CBP or FS). For example, in CBP systems, even if bedding material contains no coliforms before use, the material is a rich source of nutrition for bacteria, and therefore promotes the composting process (Husfeldt et al., 2012). However, higher temperatures $\left(55-65^{\circ} \mathrm{C}\right)$ could promote the destruction of pathogens in bedding that contains contamination before use (Stentiford, 1996), which could be advantageous for the destruction of mastitis-causing bacteria. Furthermore, if the raw material has a microbiological contamination before use, it does not have importance in the microbiological contamination after use as bedding material (Husfeldt et al., 2012).

On the other hand, in FS housing systems, the bacteria count of the original bedding material could affect both the health of dairy cows and milk contamination. According to Drissler et al. (2005), the bacterial contamination of fresh bedding may be linked to bacteria present in the older bedding in deep-bedded FS. As the depth of the material changes, new material is mixed with older bedding, which may already be contaminated.
Posidonia oceanica is a potentially useful alternative material due to its low E. coli count, TBC, coliform count, and Klebsiella spp. count. The same characteristics were also observed for triticale straw, a conventional material. Thus, both of these materials are desirable with regard to low bacterial contamination.

A summary of the physical, chemical, and biological properties of the bedding materials analyzed in the present study, as well as their suitability for different housing systems, is reported in Table 5. The suitable alternative materials for both housing systems were hemp straw, Miscanthus grass, P. oceanica, and spelt husks.

\section{CONCLUSIONS}

The physical, chemical and biological properties of conventional and alternative bedding materials for dairy cattle were evaluated in this study. The bedding materials were hierarchically clustered in 4 large groups based on the PS fraction. The physical properties exhibited substantial differences among the materials, except for the $\mathrm{BD}_{\mathrm{dry}}$, which showed no difference. With respect to the chemical properties, all of the tested materials presented desirable behavior. In addition, the contamination of each bedding material was determined for various microorganisms to determine which material had the lowest contamination. The properties of the alternative bedding materials were similar to those of the studied conventional materials. Notably, P. oceanica presented a good PS distribution, high WHC, and low

Table 5. Summary of the characteristics of the bedding materials analyzed in the present study (score ranges from -- to ++ , where ++ is very positive, - - is very negative, and $+/-$ is neutral) and their suitability for use in freestall (FS) and compost bedded pack (CBP) barns

\begin{tabular}{|c|c|c|c|c|c|c|}
\hline \multirow[b]{2}{*}{ Classification } & \multirow[b]{2}{*}{ Material } & \multirow[b]{2}{*}{$\begin{array}{c}\text { Physical } \\
\text { properties }\end{array}$} & \multirow[b]{2}{*}{$\begin{array}{l}\text { Chemical } \\
\text { properties }\end{array}$} & \multirow[b]{2}{*}{$\begin{array}{l}\text { Biological } \\
\text { properties }\end{array}$} & \multicolumn{2}{|c|}{$\begin{array}{l}\text { Suitability for use } \\
\text { in housing system }\end{array}$} \\
\hline & & & & & $\mathrm{FS}$ & $\mathrm{CBP}$ \\
\hline \multirow[t]{7}{*}{ Conventional } & Barley straw & + & $+1-$ & $+1-$ & $\mathrm{X}$ & $\mathrm{X}^{1}$ \\
\hline & Dried sawdust & ++ & ++ & - & $\mathrm{X}$ & $\mathrm{X}$ \\
\hline & Fresh sawdust & -- & ++ & $+/-$ & & \\
\hline & Triticale straw & + & - & ++ & $\mathrm{X}$ & $\mathrm{X}^{1}$ \\
\hline & Wood chips & - & + & + & $\mathrm{X}$ & $\mathrm{X}$ \\
\hline & Wood shavings & ++ & + & + & $\mathrm{X}$ & $\mathrm{X}$ \\
\hline & Wheat straw & + & - & + & $\mathrm{X}$ & $\mathrm{X}^{1}$ \\
\hline \multirow[t]{10}{*}{ Alternative } & Barley husks & $+/-$ & -- & - & & \\
\hline & Bark mulch & -- & $+/-$ & - & & \\
\hline & Conifer forest litter & - & - & -- & & \\
\hline & Flax straw & + & $+/-$ & -- & & \\
\hline & Hemp straw & $+/-$ & $+1-$ & ++ & $\mathrm{X}$ & $\mathrm{X}^{1}$ \\
\hline & Miscanthus grass & - & $+1-$ & $+/-$ & $\mathrm{X}$ & $\mathrm{X}$ \\
\hline & Posidonia oceanica & ++ & - & ++ & $\mathrm{X}$ & $\mathrm{X}$ \\
\hline & Spelt husks & $+/-$ & - & + & $\mathrm{X}$ & $\mathrm{X}$ \\
\hline & Triticale husks & + & $+/-$ & -- & & \\
\hline & Wheat husks & + & $+/-$ & -- & & \\
\hline
\end{tabular}

${ }^{1}$ Can be used successfully in CBP if processed to $<25 \mathrm{~mm}$. 
contamination of pathogen microorganisms. Based on these results, $P$. oceanica can be considered as a potential alternative material for use as bedding material for dairy cows. In addition, our work shows that Miscanthus grass and spelt husks are suitable alternative materials for use in CBP and FS systems. The experimental trials carried out in this study demonstrate that appropriate physical, chemical, and biological analyses should be performed before any material is used as bedding for dairy cattle.

\section{ACKNOWLEDGMENTS}

This research was carried out within the ERA-NET SusAn project "FreeWalk - Develop economic sound free walk farming systems elevating animal welfare, health, and manure quality while being appreciated by society." This project received funding from the European Union's Horizon 2020 Research and Innovation Program under Grant Agreement No. 696231. The authors thank the University of Florence (UNIFI, Florence, Italy), the Federal University of Lavras (UFLA, Lavras, Brazil), Wageningen University (WUR, Wageningen, the Netherlands), and the University of Ljubljana (UL, Ljubljana, Slovenia) for their partnership. The authors have not stated any conflicts of interest.

\section{REFERENCES}

Agnew, J. M., and J. J. Leonard. 2003. The physical properties of compost. Compost Sci. Util. 11:238-264. https://doi.org/10.1080/ 1065657X.2003.10702132.

Ahn, G. C., S. S. Jang, K. Y. Lee, Y. C. Baek, Y. K. Oh, and K. K. Park. 2020. Characteristics of sawdust, wood shavings and the mixture of sawdust and wood shavings by the species of pine trees, and their usefulness as bedding materials for Hanwoo cattle. Asian-Australas J Anim Sci. 33:856-865. https://doi.org/10.5713/ ajas.19.0519.

Ahn, H. K., T. L. Richard, and T. D. Glanville.. 2008. Laboratory determination of compost physical parameters for modelling of airflow characteristics. Waste Manag. 28:660-670. https://doi.org/ 10.1016/j.wasman.2007.04.008.

Albino, R. L., J. L. Taraba, M. I. Marcondes, E. A. Eckelkamp, and J. M. Bewley. 2018. Comparison of bacterial populations in bedding material, on teat ends, and in milk of cows housed in compost bedded pack barns. Anim. Prod. Sci. 58:1686-1691. https://doi.org/ 10.1071/AN16308.

ASABE. 2007. Cubes, pellets and crumbles - definitions and methods for determining density, durability and moisture content. ASAE Standard S269.4 DEC 91. American Society of Agricultural and Biological Engineers, St. Joseph, MI.

Bernhart, M., O. O. Fasina, J. Fulton, and C. W. Wood. 2010. Compaction of poultry litter. Bioresour. Technol. 101:234-238. https:/ /doi.org/10.1016/j.biortech.2009.08.030.

Bewley, J. M., L. M. Robertson, and E. A. Eckelkamp. 2017. A 100year review: Lactating dairy cattle housing management. J. Dairy Sci. 100:10418-10431. https://doi.org/10.3168/jds.2017-13251.

Black, R. A., J. L. Taraba, G. B. Day, F. A. Damasceno, and J. M. Bewley. 2013. Compost bedded pack dairy barn management, performance, and producer satisfaction. J. Dairy Sci. 96:8060-8074. https://doi.org/10.3168/jds.2013-6778.
Bramley, A. J., and F. K. Neave. 1975. Studies on the control of coliform mastitis in dairy cows. Br. Vet. J. 131:160-169. https://doi .org/10.1016/S0007-1935(17)35336-8.

Chaplin, S. J., G. Tierney, C. Stockwell, D. N. Logue, and M. Kelly. 2000. An evaluation of mattresses and mats in two dairy units. Appl. Anim. Behav. Sci. 66:263-272. https://doi.org/10.1016/ S0168-1591(99)00100-8.

Cohen, Y. 2001. Biofiltration-the treatment of fluids by microorganisms immobilized into the filter bedding material: A review. Bioresour. Technol. 77:257-274. https://doi.org/10.1016/S0960 $-8524(00) 00074-2$

Cook, N. B., T. B. Bennett, and K. V. Nordlund. 2005. Monitoring indices of cow comfort in free-stall-housed dairy herds. J. Dairy Sci. 88:3876-3885. https://doi.org/10.3168/jds.S0022-0302(05)73073 $-3$.

Cremonesi, P., B. Castiglioni, G. Malferrari, I. Biunno, C. Vimercati, P. Moroni, S. Morandi, and M. Luzzana. 2006. Improved method for rapid DNA extraction of mastitis pathogens directly from milk. J. Dairy Sci. 89:163-169. https://doi.org/10.3168/jds.S0022 -0302(06)72080-X.

Demšar, J., G. Leban, and B. Zupan. 2005. FreeViz-An intelligent visualization approach for class-labeled multidimensional data sets. Pages 13-18 in Proc. of IDAMAP. Aberdeen, Scotland, UK.

Demšar, J., G. Leban, and B. Zupan. 2007. FreeViz-An intelligent multivariate visualization approach to explorative analysis of biomedical data. J. Biomed. Inform. 40:661-671. https://doi.org/10 .1016/j.jbi.2007.03.010.

Demšar, J., and B. Zupan. 2013. Orange: Data mining fruitful and fun-A historical perspective. Informatica 37:55-60.

Dominick, D., H. Juahir, M. T. Latif, S. M. Zain, and A. Z. Aris. 2012. Spatial assessment of air quality patterns in Malaysia using multivariate analysis. Atmos. Environ. 60:172-181. https://doi.org/10 .1016/j.atmosenv.2012.06.021

Drissler, M., M. Gaworski, C. B. Tucker, and D. M. Weary. 2005. Freestall maintenance: Effects on lying behavior of dairy cattle. J. Dairy Sci. 88:2381-2387. https://doi.org/10.3168/jds.S0022 $-0302(05) 72916-7$.

Dunlop, M. W., P. J. Blackall, and R. M. Stuetz. 2015. Water addition, evaporation and water holding capacity of poultry litter. Sci. Total Environ. 538:979-985. https://doi.org/10.1016/j.scitotenv 2015.08.092.

Dunlop, M. W., P. J. Blackall, and R. M. Stuetz. 2016. Odour emissions from poultry litter-A review litter properties, odour formation and odorant emissions from porous materials. J. Environ. Manage. 177:306-319. https://doi.org/10.1016/j.jenvman.2016.04 .009 .

Eckelkamp, E. A., J. L. Taraba, K. A. Akers, R. J. Harmon, and J. M. Bewley. 2016. Understanding compost bedded pack barns: Interactions among environmental factors, bedding characteristics, and udder health. Livest. Sci. 190:35-42. https://doi.org/10.1016/ j.livsci.2016.05.017.

Fávero, S., F. V. R. Portilho, A. C. R. Oliveira, H. Langoni, and J. C. F. Pantoja. 2015. Factors associated with mastitis epidemiologic indexes, animal hygiene, and bulk milk bacterial concentrations in dairy herds housed on compost bedding. Livest. Sci. 181:220-230. https://doi.org/10.1016/j.livsci.2015.09.002.

Ferraz, P. F. P., T. Yanagi Jr., T. A. Alvarenga, G. M. Reis, and A. T. Campos. 2014. Behavior of chicks subjected to thermal challenge. Eng. Agric. 34:1039-1049. https://doi.org/10.1590/S0100 $-69162014000600002$.

Fregonesi, J. A., D. M. Veira, M. A. G. Von Keyserlingk, and D. M. Weary. 2007. Effects of bedding quality on lying behavior of dairy cows. J. Dairy Sci. 90:5468-5472. https://doi.org/10.3168/jds.2007 $-0494$.

Galama, P. J. 2014. On farm development of bedded pack dairy barns in The Netherlands: Introduction and first experiences on three farms. Report 707. Accessed May 2020. https://edepot.wur.nl/ 296350.

Godden, S., R. Bey, K. Lorch, R. Farnsworth, and P. Rapnicki. 2008. Ability of organic and inorganic bedding materials to promote 
growth of environmental bacteria. J. Dairy Sci. 91:151-159. https: //doi.org/10.3168/jds.2007-0415.

Gorden, P. J., M. D. Kleinhenz, J. A. Ydstie, T. A. Brick, L. M. Slinden, M. P. Peterson, D. E. Straub, and D. T. Burkhardt. 2018. Efficacy of vaccination with a Klebsiella pneumoniae siderophore receptor protein vaccine for reduction of Klebsiella mastitis in lactating cattle. J. Dairy Sci. 101:10398-10408. https://doi.org/10 $.3168 /$ jds.2017-14267.

Hayes, M. C., R. D. Ralyea, S. C. Murphy, N. R. Carey, J. M. Scarlett, and K. J. Boor. 2001. Identification and characterization of elevated microbial counts in bulk tank raw milk. J. Dairy Sci. 84:292-298. https://doi.org/10.3168/jds.S0022-0302(01)74479-7.

Hogan, J., and K. L. Smith. 2012. Managing environmental mastitis Vet. Clin. North Am. Food Anim. Pract. 28:217-224. https://doi .org/10.1016/j.cvfa.2012.03.009.

Hogan, J. S., and K. L. Smith. 1997. Bacteria counts in sawdust bedding. J. Dairy Sci. 80:1600-1605. https://doi.org/10.3168/jds .S0022-0302(97)76090-9.

Hogan, J. S., K. L. Smith, D. A. Todhunter, and P. S. Schoenberger. 1990. Bacterial counts associated with recycled newspaper bedding. J. Dairy Sci. 73:1756-1761. https://doi.org/10.3168/jds .S0022-0302(90)78853-4.

Husfeldt, A. W., M. I. Endres, J. A. Salfer, and K. A. Janni. 2012. Management and characteristics of recycled manure solids used for bedding in Midwest freestall dairy herds. J. Dairy Sci. 95:21952203. https://doi.org/10.3168/jds.2011-5105.

Janni, K. A., M. I. Endres, J. K. Reneau, and W. W. Schoper. 2007. Compost dairy barn layout and management recommendations. Appl. Eng. Agric. 23:97-102. https://doi.org/10.13031/2013 .22333 .

Jeppsson, K. H. 1999. Volatilization of ammonia in deep-litter systems with different bedding materials for young cattle. J. Agric. Eng. Res. 73:49-57. https://doi.org/10.1006/jaer.1998.0387.

Jobim, C. C., L. G. Nussio, R. A. Reis, and P. Schmidt. 2007. Avanços metodológicos na avaliação da qualidade da forragem conservada. Rev. Bras. Zootec. 36(Suppl. 0):101-119. https://doi.org/10.1590/ S1516-35982007001000013.

Keys, J. E. Jr., L. W. Smith, and B. T. Weinland. 1976. Response of dairy cattle given a free choice of free stall location and three bedding materials. J. Dairy Sci. 59:1157-1162. https://doi.org/10 .3168/jds.S0022-0302(76)84337-8.

Kheravii, S. K., R. A. Swick, M. Choct, and S. B. Wu. 2017. Potential of pelleted wheat straw as an alternative bedding material for broilers. Poult. Sci. 96:1641-1647. https://doi.org/10.3382/ps/ pew 473.

Kirchmann, H. 1985. Losses, plant uptake and utilisation of manure nitrogen during a production cycle. Acta Agric. Scand. (Suppl. 24):1-77.

Kirchmann, H., and E. Witter. 1989. Ammonia volatilization during aerobic and anaerobic manure decomposition. Plant Soil 115:3541. https://doi.org/10.1007/BF02220692.

Leonard, J. 2001. Composting: An alternative approach to manure management. Adv. Dairy Technol. 13:431-441.

Leso, L., M. Barbari, M. A. Lopes, F. A. Damasceno, P. Galama, J. L. Taraba, and A. Kuipers. 2020. Invited review: Compost-bedded pack barns for dairy cows. J. Dairy Sci. 103:1072-1099. https://doi .org/10.3168/jds.2019-16864.

Leso, L., L. Conti, G. Rossi, and M. Barbari. 2018. Criteria of design for deconstruction applied to dairy cows housing: A case study in Italy. Agron. Res. (Tartu) 16:794-805. https://doi.org/10.15159/ AR.18.085.

Liang, C., K. C. Das, and R. W. McClendon. 2003. The influence of temperature and moisture contents regimes on the aerobic microbial activity of a biosolids composting blend. Bioresour. Technol. 86:131-137. https://doi.org/10.1016/S0960-8524(02)00153-0.

Linden, R. 2009. Técnicas de agrupamento. Revista de Sistema de Informação da FSMA. Macaé 1:18-36.

Lybæk, R., and T. Kjaer. 2019. Pre-assessment of the circular economic benefits and challenges of biogas production in Denmark when utilizing sand bedding in dairy cow stables. J. Clean. Prod. 219:268-277. https://doi.org/10.1016/j.jclepro.2019.01.241.
Manasa, V., T. V. S. Kumar, T. P. Rao, K. A. Kumar, and K. Sireesha. 2019. Incidence of bovine clinical mastitis caused by Escherichia coli. Int. J. Curr. Microbiol. Appl. Sci. 8:1249-1256. https: //doi.org/10.20546/ijcmas.2019.805.142.

Melo Júnior, J., G. C. Sediyama, P. A. Ferreira, and B. G. Leal. 2006. Determinação de regiões homogêneas quanto à distribuição de freqüência de chuvas no leste do Estado de Minas Gerais. Revista Brasileira de Engenharia Agrícola e Ambiental, Campina Grande 10:408-416. https://doi.org/10.1590/S1415-43662006000200023.

Michel, F. C., J. Rigot, T. Wilkinson, and J. Pecchia. 2004. Effects of straw, sawdust and sand bedding on dairy manure composting. Page 1 in 2004 ASAE Annual Meeting. American Society of Agricultural and Biological Engineers. American Society of Agricultural and Biological Engineers, St. Joseph, MI.

Misra, R. V., R. N. Roy, and H. Hiraoka. 2003 On-Farm Composting Methods. UN-FAO, Rome, Italy.

Moon, J. Y., H. J. Jung, M. H. Moon, B. C. Chung, and M. H. Choi. 2009. Heat-map visualization of gas chromatography-mass spectrometry based quantitative signatures on steroid metabolism. J. Am. Soc. Mass Spectrom. 20:1626-1637. https://doi.org/10.1016/ j.jasms.2009.04.020.

Munksgaard, L., M. B. Jensen, L. J. Pedersen, S. W. Hansen, and L. Matthews. 2005. Quantifying behavioural priorities - Effects of time constraints on behaviour of dairy cows, Bos taurus. Appl. Anim. Behav. Sci. 92:3-14. https://doi.org/10.1016/j.applanim 2004.11.005.

Nakasaki, K., M. Shoda, and H. Kubota. 1986. Effects of a bulking agent on the reaction rate of thermophilic sewage sludge composting. J. Ferment. Technol. 64:539-544. https://doi.org/10.1016/ 0385-6380(86)90079-8

Norring, M., E. Manninen, A. M. De Passillé, J. Rushen, L. Munksgaard, and H. Saloniemi. 2008. Effects of sand and straw bedding on the lying behavior, cleanliness, and hoof and hock injuries of dairy cows. J. Dairy Sci. 91:570-576. https://doi.org/10.3168/jds .2007-0452.

Oliveira, L., C. Hulland, and P. L. Ruegg. 2013. Characterization of clinical mastitis occurring in cows on 50 large dairy herds in Wisconsin. J. Dairy Sci. 96:7538-7549. https://doi.org/10.3168/jds .2012-6078.

Oliveira, V. C., F. A. Damasceno, C. E. A. Oliveira, P. F. P. Ferraz, G. A. S. Ferraz, and J. A. O. Saraz. 2019. Compost-bedded pack barns in the state of Minas Gerais: Architectural and technological characterization. Agron. Res. (Tartu) 17:2016-2028. https://doi .org/10.15159/AR.19.179.

Poincelot, R. P. 1974. Scientific examination of principles and practice of composting. Compost Sci. 15:24-31.

R Development Core Team. 2019. A language and environment for statistical computing. R Foundation for Statistical Computing. Accessed Sep. 12, 2019. https://www.R-project.org/.

Reich, L. J., D. M. Weary, D. M. Veira, and M. A. G. Von Keyserlingk. 2010. Effects of sawdust bedding dry matter on lying behavior of dairy cows: A dose-dependent response. J. Dairy Sci. 93:15611565. https://doi.org/10.3168/jds.2009-2713.

Samadi, S., F. J. C. M. van Eerdenburg, A. R. Jamshidifard, G. P. Otten, M. Droppert, D. J. J. Heederik, and I. M. Wouters. 2012. The influence of bedding materials on bio-aerosol exposure in dairy barns. J. Expo. Sci. Environ. Epidemiol. 22:361-368. https://doi .org/10.1038/jes.2012.25.

Schukken, Y. H., G. J. Bennett, M. J. Zurakowski, H. L. Sharkey, B. J. Rauch, M. J. Thomas, B. Ceglowski, R. L. Saltman, N. Belomestnykh, and R. N. Zadoks. 2011. Randomized clinical trial to evaluate the efficacy of a 5-day ceftiofur hydrochloride intramammary treatment on nonsevere gram-negative clinical mastitis. J. Dairy Sci. 94:6203-6215. https://doi.org/10.3168/jds.2011-4290.

Seegers, H., C. Fourichon, and F. Beaudeau. 2003. Production effects related to mastitis and mastitis economics in dairy cattle herds. Vet. Res. 34:475-491. https://doi.org/10.1051/vetres:2003027.

Shane, E. M., M. I. Endres, D. G. Johnson, and J. K. Reneau. 2010. Bedding options for an alternative housing system for dairy cows: A descriptive study. Appl. Eng. Agric. 26:659-666. https://doi .org/10.13031/2013.32062. 
Smith, M. M., C. L. Simms, and J. D. Aber. 2017. Case Study: Animal bedding cost and somatic cell count across New England dairy farms: Relationship with bedding material, housing type, herd size, and management system. Prof. Anim. Sci. 33:616-626. https: //doi.org/10.15232/pas.2016-01601.

Standards Australia. 2003. Potting Mixes (AS 3743-2003). Standards Australia/Standards New Zealand, Sydney.

Stentiford, E. I. 1996. Composting control: Principles and practice. Pages 49-59 in The Science of Composting. Springer, Dordrecht, the Netherlands.

Tchobanoglous, G., H. Theisen, and A. S. Vigil. 1993. Integrated Solid Waste Management: Engineering Principles and Management Issues. McGraw-Hill, New York, NY.

Tucker, C. B., and D. M. Weary. 2004. Bedding on geotextile mattresses: How much is needed to improve cow comfort? J. Dairy Sci. 87:2889-2895. https://doi.org/10.3168/jds.S0022-0302(04)73419 -0 .

Tucker, C. B., D. M. Weary, M. A. G. Von Keyserlingk, and K. A. Beauchemin. 2009. Cow comfort in tie-stalls: Increased depth of shavings or straw bedding increases lying time. J. Dairy Sci. 92:2684-2690. https://doi.org/10.3168/jds.2008-1926.

Van Dooren, H. J. C., P. J. Galama, and K. Blanken. 2016. On farm development of bedded pack dairy barns in The Netherlands: Gaseous emissions from bedding. Report 710. Accessed May 2020. https://edepot.wur.nl/393409.

Van Dooren, H. J. C., F. Sanderink, A. Hol, and P. J. Galama. 2018. Gaseous emissions of bedded pack barns with wood chips and compost as bedding material. Pages 103-116 in Air Quality and Livestock Farming. CRC Press, Boca Raton, FL.

van Gastelen, S., B. Westerlaan, D. J. Houwers, and F. J. C. M. Van Eerdenburg. 2011. A study on cow comfort and risk for lameness and mastitis in relation to different types of bedding materials. J. Dairy Sci. 94:4878-4888. https://doi.org/10.3168/jds.2010-4019.

Wilkinson, L., and M. Friendly. 2009. The history of the cluster heat map. Am. Stat. 63:179-184. https://doi.org/10.1198/tas.2009 .0033 .

Wolfe, T., E. Vasseur, T. J. DeVries, and R. Bergeron. 2018. Effects of alternative deep bedding options on dairy cow preference, lying behavior, cleanliness, and teat end contamination. J. Dairy Sci. 101:530-536. https://doi.org/10.3168/jds.2016-12358.

Yajima, A., H. Owada, S. Kobayashi, N. Komatsu, K. Takehara, M. Ito, K. Matsuda, K. Sato, H. Itabashi, S. Sugimura, and S. Kanda. 2017. Cacao bean husk: An applicable bedding material in dairy free-stall barns. Asian-Australas. J. Anim. Sci. 30:1048-1053. https://doi.org/10.5713/ajas.16.0877.

Zehner, M. M., R. J. Farnsworth, R. D. Appleman, K. Larntz, and J. A. Springer. 1986. Growth of environmental mastitis pathogens in various bedding materials. J. Dairy Sci. 69:1932-1941. https://doi .org/10.3168/jds.S0022-0302(86)80620-8.

\section{ORCIDS}

Patrícia Ferreira Ponciano Ferraz @ https://orcid.org/0000-0002-9708 $-0259$

Gabriel Araújo e Silva Ferraz (i) https://orcid.org/0000-0001-6403 $-2210$

Lorenzo Leso (ํ) https://orcid.org/0000-0003-4274-3921

Marija Klopčič @ https://orcid.org/0000-0003-0790-980X

Matteo Barbari ๑ https://orcid.org/0000-0002-0760-8604

Giuseppe Rossi @ https://orcid.org/0000-0003-0211-9294 